\title{
Protease-activated receptors in cancer: A systematic review
}

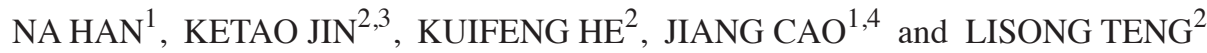 \\ ${ }^{1}$ Sir Run Run Shaw Institute of Clinical Medicine, Zhejiang University: Key Laboratory of Biotherapy of Zhejiang Province, \\ Zhejiang University, Hangzhou, Zhejiang 310016; ${ }^{2}$ Department of Surgical Oncology, First Affiliated Hospital, \\ College of Medicine, Zhejiang University, Hangzhou, Zhejiang 310003 ; ${ }^{3}$ Department of Surgery, \\ Zhuji Hospital, Wenzhou Medical College, Zhuji, Zhejiang 311800; ${ }^{4}$ Clinical Research Center, \\ Second Affiliated Hospital, College of Medicine, Zhejiang University, Hangzhou, Zhejiang 310003, P.R. China
}

Received January 12, 2011; Accepted April 6, 2011

DOI: $10.3892 / \mathrm{ol} .2011 .291$

\begin{abstract}
The traditional view of the role of proteases in tumor growth, progression and metastasis has significantly changed. Apart from their contribution to cancer progression, it is evident that a subclass of proteases, such as thrombin, serves as signal molecules controlling cell functions through the protease-activated receptors (PARs). Among the four types of PAR (PAR1-4; cloned and named in order of their discovery), PAR1, PAR3 and PAR4 are activated by thrombin, unlike PAR2, which is activated by trypsin-like serine proteases. Thrombin has been proven to be a significant factor in both the behavior of cancer in its involvement in hemostasis and blood coagulation. Thrombin is a key supporter of various cellular effects relevant to tumor growth and metastasis, as well as a potent activator of angiogenesis, which is essential for the growth and development of all solid tumor types. This review presents an overview of the role of PAR-mediated thrombin in angiogenesis and cancer, focusing on the ability of PAR1- and PAR4-mediated thrombin to affect tumorigenesis and angiogenesis.
\end{abstract}

\section{Contents}

1. Introduction

2. Thrombin level in cancer and PAR activation

Correspondence to: Dr Jiang Cao, Sir Run Run Shaw Institute of Clinical Medicine, Zhejiang University: Key Laboratory of Biotherapy of Zhejiang Province, and Clinical Research Center, Second Affiliated Hospital, College of Medicine, Zhejiang University, 88 Jiefang Road, Hangzhou, Zhejiang 310003, P.R. China E-mail: jinketao2001@zju.edu.cn

Dr Lisong Teng, Department of Surgical Oncology, First Affiliated Hospital, College of Medicine, Zhejiang University, 79 Qingchun Road, Hangzhou, Zhejiang 310003, P.R. China

E-mail: 1steng@zju.edu.cn

Key words: angiogenesis, cancer, protease-activated receptors, tumorigenesis
3. Thrombin and PAR in angiogenesis

4. Thrombin and PAR in tumorigenesis and metastasis

5. Therapeutic implications in cancer

6. Conclusions

\section{Introduction}

The G-protein-coupled receptor (GPCR) superfamily comprises the largest and most functionally diverse group of signaling molecules. These receptors play essential roles in the normal regulation of the majority of biological processes. They are also of great significance in human diseases, such as cancer. GPCRs are able to interact with a variety of agonists, such as peptides, lipids and ions. Proteases are one of the most noteworthy agonists of GPCRs.

Proteases have previously been associated with tumor progression due to their ability to degrade extracellular matrices, facilitating tumor cell invasion and metastasis (1). However, studies have shown that these enzymes target diverse substrates and promote tumor evolution (2), a fact that significantly altered the traditional view of the role of proteases in tumor growth and progression. It is well known that a subclass of proteases serves as signal molecules controlling cell functions through specific GPCRs, the protease-activated receptors (PARs) $(3,4)$. The PARs are activated by low concentrations of certain extracellular serine proteases.

Four types of PAR (PAR1-4) have been cloned and named in order of their discovery. These PARs share the same basic mechanism of activation in that proteases cleave at a specific site within the extracellular $\mathrm{N}$-terminus to expose a new N-terminal tethered ligand domain, which binds to and activates the cleaved receptor. PAR1, PAR3 and PAR4 are activated by thrombin, one of the important extracellular serine proteases $(5,6)$. On the other hand, PAR 2 is activated by trypsin-like serine proteases, including trypsin, tryptase and coagulation proteases upstream of thrombin, tissue factors (TFs) VIIa and Xa, but not by thrombin (4,7-12).

Thrombin has been proven to be crucial in the behavior of cancer and in its involvement in hemostasis and blood coagulation. Thrombin is a key supporter of various cellular effects relevant to tumor growth and metastasis as well as a potent 
activator of angiogenesis, which is essential for the growth and development of all solid tumor types. Thrombin actions in cancer are PAR-mediated.

This review provides an overview of the role of PARmediated thrombin actions in cancer, focusing on the involvement of PAR1- and PAR4-mediated thrombin in tumorigenesis and angiogenesis.

\section{Thrombin level in cancer and PAR activation}

Thrombin generated in the circulation during activation of the coagulation cascade has multiple cellular effects, including the induction of cell proliferation and motility, enhancement of vascular permeability, deposition of matrix fibrin, promotion of tumor cell seeding, adhesion to endothelium and extracellular matrix, induction of platelet aggregation, and enhancement of the metastatic capacity of tumors $(13,14)$. A common feature in cancer patients is the high level of thrombin formation in tumor cells. It has been shown that numerous tumor cell types express the transmembrane protein tissue factor, which, when exposed to circulating factor VII, activates factor $\mathrm{X}$, leading to the generation of thrombin (15). Thrombin generation is possibly a direct result of the overactivation of the coagulation system (hypercoagulability), a widely described abnormality in various cancer patients (16).

Thrombin activates PAR1, PAR3 and PAR4. Thrombin activates PAR1 in two stages (9). Firstly, it binds to PAR1 on either side of the cleavage site. Secondly, it cleaves PAR1 between $\mathrm{Arg}^{41}$ and $\mathrm{Ser}^{42}$ to expose a new N-terminal tethered ligand domain, SFLLRN. The tethered ligand interacts with domains in extracellular loop 2, which presumably alters the conformation of the receptor to permit coupling to G-proteins. PAR3 also contains the thrombin binding sites, whereas PAR4 lacks thrombin binding sites and only responds to higher concentrations of thrombin $(5,11)$. The differences in the mechanism of activation mentioned above exhibit functional consequences in tumorigenesis and angiogenesis.

\section{Thrombin and PARs in angiogenesis}

Action of PAR-mediated thrombin on endothelial cells. Although thrombin is best known for its direct role in clot formation via platelet activation and fibrin deposition, a number of the effects of thrombin in cancer may be mediated by promoting angiogenesis in vivo (17-19). Numerous cellular effects of thrombin on endothelial cells contribute to the angiogenic action of thrombin (Table I) (17-30).

Angiogenesis involves the activation and invasion of the endothelial cells through their basement membrane and migration to distal sites. Studies have demonstrated that thrombin contributes to each of these events $(18,19,23-25)$. This cellular action of thrombin on endothelial cell adhesion may indicate a significant role in the activation of the normally quiescent endothelial cells in the initiation of the angiogenic cascade. A key event in early angiogenesis is the local dissolution of the basement membrane of the parent vessel. Endothelial cells need to overcome the barrier of their anchorage to basement membrane components in order to migrate to distal sites, proliferate and form the lumen of the new vessel. Exposure of endothelial cells to thrombin causes a
Table I. Effects of PAR-mediated thrombin on endothelial cells.

\begin{tabular}{lcc}
\hline & PAR-mediated & Refs. \\
\hline Effects of thrombin & PAR1-, PAR3- and & 17, \\
on ECs & PAR4-mediated & $20-22$ \\
Decrease in the attachment & & 18,19, \\
of ECs to BMC & 23,24 \\
Increase in MMP-2 activation & 25 \\
Up-regulation of integrin $\alpha_{v} \beta_{3}$ & 19,25, \\
& 26 \\
Chemotactic and aptotactic & 27 \\
effects on ECs & \\
Up-regulation of VEGF & 27 \\
receptors (KDR and Flt1) & \\
Up-regulation of VEGF & 28 \\
Synergy with VEGF & 27 \\
in EC proliferation & \\
Vascular smooth & \\
muscle cell migration & 29,30
\end{tabular}

ECs, endothelial cells; BMC, basement membrane components; MMP-2, matrix metalloproteinase 2; VEGF, vascular endothelial growth factor.

time- and dose-dependent decrease in the attachment of these cells to basement membrane components, with a concomitant increase in matrix metalloproteinase 2 (MMP-2) activation $(24,25)$. This decrease not only allows for the migration of endothelial cells, but releases other angiogenic factors that are sequestered in the extracellular matrix.

Integrin $\alpha_{v} \beta_{3}$ was identified as a marker of the angiogenic phenotype of endothelial cells in vascular tissue (31). Antibodies or peptide antagonists of this integrin inhibited angiogenesis induced by basic fibroblast growth factor in the rabbit cornea model (26). Furthermore, integrin $\alpha_{v} \beta_{3}$ antagonists inhibit tumor-induced angiogenesis by inducing apoptosis in angiogenic blood vessels without affecting mature vessels, which express minimal $\alpha_{v} \beta_{3}$. Endothelial cells attach to thrombin via the angiogenic integrin $\alpha_{\mathrm{v}} \beta_{3}$, which is up-regulated by thrombin $(19,25)$. This attachment provides endothelial cells with survival signals during their anchorage-independent migration (19). More importantly, both integrin $\alpha_{v} \beta_{3}$ and MMP-2 functionally coexist on the surface of angiogenic capillaries (26).

Thrombin also has chemotactic and aptotactic effects on endothelial cells in that it up-regulates the expression of the vascular endothelial growth factor (VEGF) receptors (KDR and Flt1) and synergizes with the key angiogenic factor VEGF in endothelial cell proliferation (27). It has been shown that 8-12 h after exposure of endothelial cells to thrombin, cells are sensitized to the action of VEGF. The mitogenic activity is increased by more than $100 \%$ over the level expected from the additive effects of thrombin and VEGF alone. The thrombin-treated cells respond to VEGF-induced DNA synthesis in a synergistic manner (27). This synergistic effect 
Table II. Dual regulation of platelets on angiogenesis.

\begin{tabular}{lcc}
\hline $\begin{array}{l}\text { Dual regulation of platelets } \\
\text { on angiogenesis }\end{array}$ & PAR-mediated & Refs. \\
\hline $\begin{array}{l}\text { Pro-angiogenic regulation } \\
\text { of platelets by releasing }\end{array}$ & PAR1-mediated & 50 \\
$\begin{array}{l}\text { angiogenic promoters: } \\
\text { VEGF }\end{array}$ & $42,45,48$, \\
& & $51-58$ \\
bFGF & \\
EGF & \\
PDGF & \\
MMPs & \\
Anti-angiogenic regulation & PAR4-mediated \\
of platelets by releasing & \\
angiogenic inhibitors: & \\
Endostatin & \\
Platelet factor-4 & \\
Thrombospondin-1 & \\
2-macroglobulin & \\
Plasminogen activator & \\
inhibitor-1 & \\
Angiostatin & \\
\hline
\end{tabular}

VEGF, vascular endothelial growth factor; bFGF, basic fibroblast growth factor; EGF, epidermal growth factor; PDGF, platelet derived growth factor; MMPs, matrix metalloproteinases.

of thrombin with VEGF can be explained by the finding that thrombin increases the level of VEGF receptors KDR and Flt-1 as mentioned above.

The PAR family members, PAR1, PAR2, PAR3 and PAR4, are expressed in arterial and/or venous endothelial cells (20,22,32-34). Endothelial PARs serve as sensors of extracellular proteases and transmit signals after cleavage by proteases such as thrombin $(35,36)$. Previous studies indicated that coagulation factors upstream and downstream of thrombin mediate the activation of PAR1 in endothelial cells (35-37). Thrombin activation of PAR1 generates cytoskeletal rearrangements in endothelial cells and induces cell contraction and rounding $(38,39)$. Endothelial cell contraction destabilizes cell-cell contacts, causing a subsequent increase in vascular permeability that facilitates the passage of molecules and cells from the blood into subendothelial compartments. Activation of PAR1 in the vascular endothelium also leads to increased surface expression of the adhesion molecules, such as intercellular adhesion molecule-1, vascular cell adhesion molecule-1, P-selectin and E-selectin (40).

Action of PAR-mediated thrombin on platelets. The process of postnatal angiogenesis is regulated by a continuous interplay of stimulators and inhibitors of angiogenesis, and their imbalance contributes to numerous inflammatory, malignant, ischemic and immune disorders (41). A renewed interest in the overlap between angiogenesis and platelets has been observed (42) with findings of various clinical trials showing that anticoagulation improves cancer survival $(43,44)$ beyond the benefit derived from the treatment of deep vein thrombosis alone. Platelets act as the initial responder to vascular change and provide a flexible delivery system for angiogenesis-related molecules (45-48).

It is known that platelets stimulate endothelial cells in culture and promote the assembly of capillary-like structures in vitro (49). Platelets may modulate angiogenesis by releasing promoters, such as VEGF, basic fibroblast growth factor (bFGF), epidermal growth factor (EGF), platelet-derived growth factor (PDGF) and matrix metalloproteinases (MMPs) (Table II) $(42,45,48,50-58)$. Platelets comprise a wide range of angiogenesis inhibitors including endostatin, platelet factor-4, thrombospondin-1, 2-macroglobulin, plasminogen activator inhibitor-1 and angiostatin (Table II) $(48,59,60)$. Although platelets contain three types of secretory granules ( $\alpha$-granules, dense granules and lysosomes), most angiogenic regulatory proteins have been localized to $\alpha$-granules. $\alpha$-granules comprise proteins that enhance the adhesive process, promote cell-cell interactions and stimulate vascular repair. By adhering to the endothelium of injured organs and tissues and then secreting the contents of their $\alpha$-granules, platelets may be capable of depositing high concentrations of angiogenesis regulatory proteins in a localized manner (50).

Platelets are regulated through numerous agonist-induced signaling pathways, the most potent of which is thrombin $(61,62)$. Human platelets express two functional thrombin receptors, PAR1 and PAR4 (63-65). Thrombin acts through PAR1 and PAR4 on human platelets to signal activation responses, such as calcium mobilization, release of procoagulant molecules (e.g., P-selectin) from $\alpha$-granules, release of small molecules (e.g., ADP) from dense granules, activation of glycoprotein IIbIIIa/integrin $\alpha_{\text {IIb }} \beta_{3}$ (GPIIbIIIa) and aggregation (65-72). Thrombin activates PAR1 at concentrations 10-fold less than PAR4, but activation of PAR4 provides a longer stimulus $(61,73)$.

Numerous experimental data and clinical investigations have suggested that platelets are major regulators of angiogenesis. However, since platelets contain both pro- and anti-angiogenic regulatory proteins and because it has been assumed that the contents of $\alpha$-granules are homogeneous, it is unclear how platelets either stimulate or inhibit angiogenesis. Italiano et al (50) provided new details about the organization of angiogenesis regulatory proteins in the $\alpha$-granules of platelets and addressed the mechanism of how the selective release of these granules leads to the regulation of angiogenesis. Using double immunofluorescence and immunoelectron microscopy, these authors showed that pro- and anti-angiogenic proteins are divided into distinct subpopulations of $\alpha$-granules in platelets and megakaryocytes. The double immunofluorescence labeling of VEGF and endostatin, or that for thrombospondin-1 and bFGF, confirms the segregation of stimulators and inhibitors into separate and distinct $\alpha$-granules. These observations motivated the hypothesis that distinct populations of $\alpha$-granules undergo selective release. Furthermore, the treatment of human platelets with a selective PAR4 agonist (AYPGKF-NH2) resulted in the release of endostatin-containing, but not VEGF-containing granules, whereas the selective PAR1 agonist (TFLLR-NH2) released VEGF, but not endostatin-containing granules. Results of this 
Table III. Activity of PAR-mediated thrombin in tumorigenesis.

\begin{tabular}{|c|c|c|c|c|}
\hline Tumor types & PAR-mediated & Activity & In vivo/In vitro & Refs. \\
\hline Colon carcinoma & Not available & Amplifying tumor-platelet adhesion & In vitro & 74 \\
\hline Melanoma & Not available & Amplifying tumor-platelet adhesion & In vitro & 74 \\
\hline Melanoma & Not available & Increasing adhesion to platelets & In vivo & 75 \\
\hline Melanoma & Not available & Promoting cell proliferation & In vivo & 75 \\
\hline Colon carcinoma & Not available & Increasing adhesion to platelets & In vivo & 75 \\
\hline Colon carcinoma & Not available & Promoting cell proliferation & In vivo & 75 \\
\hline Colon carcinoma & PAR1-mediated & Inducing cell proliferation and motility & In vitro & 76 \\
\hline Colon carcinoma & PAR1-mediated & Promoting cell proliferation & In vitro & 77 \\
\hline Colon carcinoma & Not available & Promoting adhesion and migration & In vitro & 78 \\
\hline Human chondrosarcoma & PAR1-, PAR4-mediated & Promoting cell proliferation & In vitro & 79 \\
\hline Hepatocellular carcinoma & PAR1-, PAR4-mediated & Promoting cell migration & In vitro & 80 \\
\hline Gastric carcinoma & PAR2-mediated & Promoting cell proliferation & In vitro & 81 \\
\hline
\end{tabular}

Table IV. Activity of PAR-mediated thrombin in tumor invasion and metastasis.

\begin{tabular}{lllr}
\hline Tumor types & PAR-mediated & Activity & In vivo/In vitro \\
\hline Colon carcinoma & Not available & Promoting metastases & In vivo \\
Colon carcinoma & Not available & Promoting metastases & In vivo \\
Melanoma & Not available & Promoting metastases & In vivo \\
Melanoma & Not available & Promoting metastases & In vivo \\
Melanoma & Not available & Promoting metastases & In vivo \\
Melanoma & PAR1-mediated & Promoting metastases & In vivo \\
Melanoma & PAR1-mediated & Promoting metastases & In vivo \\
Melanoma & PAR1-, PAR2-mediated & Promoting metastases & In vivo \\
Melanoma & PAR1-mediated & Promoting cell invasion & In vitro \\
Renal cancer & PAR1-mediated & Promoting cell invasion & In vitro \\
Breast cancer & PAR1-mediated & Promoting cell invasion & 110 \\
Breast cancer & Not available & Promoting cell invasion & 112 \\
& In vitro & 113 \\
\end{tabular}

study (50) demonstrated the separate packaging of angiogenesis regulators into pharmacologically and morphologically distinct populations of $\alpha$-granules in platelets and may provide a mechanism by which platelets locally stimulate or inhibit angiogenesis. Tumors may hijack the angiogenic properties of platelets to generate new blood vessel growth by manipulating the PARs on platelets and triggering the selective release of predominantly proangiogenic factors.

\section{Thrombin and PARs in tumorigenesis and metastasis}

Action of PAR-mediated thrombin in tumorigenesis. Thrombin markedly increases the growth potential of tumor cells (Table III) (74-81), although these effects may be partially attributed to its pro-angiogenic effects $(27,82)$. By mobilizing adhesion molecules, such as the $\alpha_{\mathrm{IIb}} \beta_{3}$ integrin (83-85), P-selectin $(86,87)$ and CD40 ligand (88) to the cell surface, thrombin enhances adhesion between tumor cells, platelets, endothelial cells and the extracellular matrix, and contributes to tumor progression. Thrombin also triggers the release of growth factors (89), chemokines and extracellular proteins (90) that promote the proliferation and migration of tumor cells.

The microenvironment of tumors is replete with thrombin, which activates PARs, and tumor cells, which also express PARs. Malignant cells secrete thrombin, which affects proliferation and mediates metastatic processes, such as cellular invasion, extracellular matrix degradation, angiogenesis and tissue remodeling. In the setting of cancer, the ability of thrombin to act via PARs was highlighted by the demonstration of PAR expression in carcinosarcoma (91). Additionally, mounting evidence showed that the PAR family is involved in neoplasia (92). In particular, PAR1 is expressed by a wide range of tumor cells (91,93-96). The expression of PAR1 has been correlated with the malignant phenotype. For PAR1, a role in the progression of epithelial tumors, including breast $(75,82,94,97,98)$, colon $(76,99)$, kidney $(100)$, pulmonary tumor (101), melanoma (102) and hepatocellular carcinoma $(80,103)$ has been shown.

The effects of thrombin in human colon cancer cells have been found to be mediated by functional PAR4. Firstly, the 
Table V. PAR1 and PAR4 antagonists.

\begin{tabular}{lllr}
\hline PAR1 antagonists & \multicolumn{1}{c}{ Characteristic } & Selectivity & Refs. \\
\hline AFLARAA & $\begin{array}{l}\text { Peptide with multiple alanine substitutions } \\
\text { in both critical and non-critical } \\
\text { residues of SFLLRN }\end{array}$ & Not available & 134 \\
Anti-PAR1 pepducin (P1pal-12) & $\begin{array}{l}\text { Palmitoylated peptide based on } \\
\text { the human PAR1 i3 loop }\end{array}$ & PAR1 selective & 135,136 \\
FR-171113 & Non-peptide PAR1 antagonist & PAR1 selective & 137 \\
RWJ-56110 & Peptide-mimetic PAR1 antagonists & $138-140$ \\
RWJ-58259 & Indole-based SFLLR peptide mimetic & PAR1 selective & $140-142$ \\
SCH-328725 & Non-peptide PAR1 antagonist based on & PAR1 selective & 137 \\
the natural product himbacine & PAR1 selective & 143 \\
SCH-205831 & $\begin{array}{l}\text { Non-peptide PAR1 antagonist based on } \\
\text { the natural product himbacine }\end{array}$ & PAR1 selective & 144 \\
SCH-79797 & $\begin{array}{l}\text { Non-peptide PAR1 antagonist based on } \\
\text { the natural product himbacine }\end{array}$ & PAR1 selective & 145,146 \\
BMS-200261 & Peptide-mimetic PAR1 antagonists & 146 \\
BMS-200661 & Peptide-mimetic PAR1 antagonists & PAR1 selective & 146 \\
BMS-200260 & Peptide-mimetic PAR1 antagonists & PAR1 selective & $147-149$ \\
tc-Y-NH2 & Trans-cinnamoyl (tc-) PAR4 peptide analogue & PAR1 selective & PAR4 selective \\
Anti-PAR4 pepducin (P4pal-10) & Palmitoylated peptide based on & Higher selectivity for & 135,136, \\
the human PAR4 i3 loop & PAR4 over PAR1 & 147,150 \\
YD-3 & Non-peptide PAR4 antagonist & PAR4 selective & 138,151 \\
P20.1 & Monoclonal antibody directed against & PAR4 selective & 152 \\
& the N-terminal 20 amino acid portion & & \\
& of human PAR4 & & \\
\hline
\end{tabular}

PAR4 agonist AP4 mimics the effects of thrombin on cell proliferation. However, AP4 does not activate other PARs. Secondly, the challenge of CHO-PAR4-expressing cells with AP4 has the same impact on calcium transients as that in HT-29 cells. Thirdly, no effect on calcium transients is noted following the challenge of HT-29 cells with reverse peptide. AP4 was capable of promoting colon cancer cell proliferation since, at maximally active concentrations, its effect exhibited up to a $250 \%$ increase in the cell number in HT-29 cells. PAR4 should thus be regarded as a crucial receptor by which thrombin modulates colon carcinogenesis (104).

Action of PAR-mediated thrombin in tumor metastasis. Tumor cell metastasis or the dissemination of a tumor from its original site to distant organs and tissues is an inherently inefficient process. The ability of tumor cells to activate the coagulation system and to generate thrombin has been shown to enhance metastatic efficiency (105-108), while anticoagulant therapies interfere with metastatic disease in animal models and in humans (109). The prometastatic activity of thrombin in cancer has been well demonstrated (Table IV) (74,75,82,84,97,98,110-113). The principal thrombin receptor, PAR1, has been implicated in the promotion of these effects (Table IV).

PAR1 expression is correlated with metastatic potential. In human breast cancer, PAR1 expression is associated with tumor progression (82), and in prostate cancer it plays a role in bone metastasis (114). Metastatic human melanoma cell lines express PAR1 $(102,110)$. The overexpression of PAR1 in murine and human melanoma cells results in enhanced metastasis in mice $(98,115)$. The overexpression of PAR1 also increases matrigel invasion by melanoma cells (112) and thrombin stimulates the motility of colon carcinoma cells in a PAR1-dependent manner (76,78). PAR1 antisense markedly reduces the invasion of a metastatic breast cancer cell line through a matrigel barrier (82). Pre-treatment of tumor cells with PAR1 agonist peptides alters their adhesive behavior and increases pulmonary metastasis (98). Thrombin-dependent PAR1 signaling induces the proliferation of metastatic tumor cells (116) and can be anti-apoptotic (117). PAR1 enhances the $\alpha_{v} \beta_{5}$ integrin-dependent migration of tumor cells (118). PAR1 has also been proposed to play a role in the pathological invasion processes of breast cancer $(82,97)$.

The prometastatic effects of thrombin on tumor cells may involve the receptor cross-activation of PAR2, due to the fact that the metastasis was enhanced by PAR2 stimulation (111). Although the precise mechanism of PAR2 signaling in metastasis remains to be determined, it is known that the tethered ligand of PAR1 activates PAR2. PAR2 may thus be activated by thrombin-cleaved PAR1, and PAR 2 may act as a relevant receptor for thrombin signaling under certain conditions (119).

\section{Therapeutic implications in cancer}

The angiogenic and tumor-promoting effects of thrombin provide the basis for the development of thrombin receptor antagonists for therapeutic application in cancer. A number 
of promising targets may be utilitzed for drug discovery for cancer therapeutics within the clotting cascade. Therapeutic approaches to down-regulating thrombin generation in cancer may accomplish three goals: anticoagulation, prevention of angiogenesis and prevention of tumor growth and metastasis.

Thrombin directly affects signaling pathways that mediate cell functions and clot formation, which provide a growth medium for tumor cells. Therefore, anticoagulant drugs may prove efficacious in cancer treatment as they are capable of reducing the hypercoagulability of cancer. Thrombin-targeted anticoagulant strategies designed to affect both the prothrombotic properties of tumors and their growth and metastatic potential, have been evaluated in a number of pre-clinical and clinical studies (120-122). However, studies providing convincing evidence that this approach predictably improves survival in cancer are limited $(43,44)$.

Since it is believed that all tumors require angiogenesis for tumor growth and metastasis, targeting tumor vasculature with anti-angiogenic agents has developed into a novel strategy for treating a number of solid tumors $(123,124)$. Anti-angiogenic agents generally elicit few toxic side effects in contrast to standard chemotherapeutic agents. Nevertheless, patients treated with both anti-angiogenic agents and standard chemotherapy resulted in an unexpected high incidence of both arterial and venous thrombosis, as reported in a number of clinical trials $(123,125)$. This serious complication has been observed with various promising anti-angiogenic agents, including VEGF Trap $(124,125)$. It is plausible that synergistic vascular toxicity occurs between anti-angiogenic agents and chemotherapy drugs since virtually all chemotherapeutic agents injected intravenously stimulated increased thrombin generation (126). Therefore, adding thrombin-targeted anticoagulants to combination drug regimens, including agents that interact with the endothelium, may aid in the prevention of some of these thrombotic complications by blocking thrombin generation (126,127). Further stimulation for the addition of anticoagulants to cancer treatment regimens is evident in recent experimental studies in which non-anticoagulant properties of anticoagulant drugs have been exploited to reduce angiogenesis, tumor growth and metastasis (128-131). Combination regimens of standard chemotherapeutics with anticoagulants may provide added benefit for control of tumor progression and simultaneously reduce the risks for serious thrombotic complications. However, such a hypothesis should be confirmed by prospective randomized controlled clinical trials of anticoagulant drugs in cancer.

Inhibitors of thrombin have achieved success in anticoagulant therapy, but are also accompanied with the risk of bleeding $(132,133)$. PARs themselves were considered to be attractive targets for therapeutic drug development. Efforts to develop receptor inhibitors as compared to targeting thrombin are currently regarded as a priority. As outlined in Table V (134-152), substantial success has been achieved in the development of PAR1 and PAR4 antagonists.

PAR antagonists act by blocking the interaction of the newly exposed tethered ligand with binding sites on the extracellular surface of the receptor, but do not inhibit thrombin binding or receptor cleavage. Small molecule PAR1 antagonists have been generated based on the structure of the peptide ligand for PAR1 (4). Bradykinin-derived blocking peptides appear to directly bind and suppress PAR1 activation and do not act as thrombin inhibitors (137). However, a number of these molecules lack PAR1 selectivity due to structural similarities to activating peptides of other PARs. More selective and potent non-peptide PAR1 antagonists for both experimental studies and pharmaceutical use in humans are also currently available (7,137,139-143). In addition to increased PAR1 selectivity, these compounds exhibit relatively potent inhibitory actions against both thrombin and agonist/peptide-stimulated responses. The orally active PAR1 antagonist developed by Schering (SCH-205831), which suppresses PAR1 by competitively inhibiting the TL-binding site (143), has been found to be effective as an antithrombotic agent in humans. A number of other PAR1 antagonists and monoclonal antibodies generated against the cleavage site of PAR1 have also been used to block the activation of PAR1, but their use is limited by relatively low efficacies $(134,146$, 153-155). The development of effective PAR1 antagonists is in the early stages. However, further description and classification of the recently developed compounds is likely to yield crucial data towards generating novel effective antagonists for PAR1, as well as for other PARs.

PAR4 antagonism has also been shown using the peptide trans-cinnamoyl-YPGKF-NH $\mathrm{NH}_{2}$ in human platelets (148), although its use in vivo was limited to its non-PAR actions (156). A novel approach to receptor inhibition, through targeting the receptor intracellular loops with palmitoylated membrane-penetrating peptides termed pepducins, has succeeded in developing a relatively high potency PAR4 antagonist $(135,150,157)$. Pepducin, P4pal-10, has been proven to be of use in blocking PAR4 activation both in vivo and in vitro $(135,157)$, although it is not completely selective for PAR4 (156).

\section{Conclusions}

Evidence of PAR-mediated thrombin functions in angiogenesis, tumorigenesis and metastasis is well established, as mentioned above. PAR-mediated thrombin exerts its effects in cancer indirectly by promoting angiogenesis, which is essential for the growth and development of all solid tumor types, and directly by promoting tumor growth and metastasis. The key objective of investigating the role of PAR-mediated thrombin in cancer is to develop thrombin-targeted drugs and PAR antagonists for therapeutic application in cancer treatment. Thrombin-targeted anticoagulant strategies designed to affect both the prothrombotic properties of tumors and their growth and metastatic potential have been evaluated in a number of pre-clinical and clinical studies. However, studies providing evidence that this approach may predictably improve survival in cancer are limited. Therapeutic approaches that target PARs themselves were considered to be attractive targets for therapeutic drug development. The development of effective PAR antagonists, however, remains in the early stages.

\section{Acknowledgements}

This study was supported by the State Key Basic Research and Development Program of China (973 Program, Grant No. 2009CB521704), the National High-tech Research and 
Development Program of China (863 Program, Grant No. 2006AA02A245), the National Natural Science Foundation of China (Grant No. 30271450 and 30672365) and the Zhejiang Provincial Science and Technology Project (Grant No. 2009C13021).

\section{References}

1. Mook OR, Frederiks WM and van Noorden CJ: The role of gelatinases in colorectal cancer progression and metastasis. Biochim Biophys Acta 1705: 69-89, 2004.

2. López-Otín C and Matrisian LM: Emerging roles of proteases in tumour suppression. Nat Rev Cancer 7: 800-808, 2007.

3. Déry O, Corvera CU, Steinhoff M and Bunnett NW: Proteinaseactivated receptors: novel mechanisms of signaling by serine proteases. Am J Physiol 274: C1429-C1452, 1998.

4. Macfarlane SR, Seatter MJ, Kanke T, Hunter GD and Plevin R: Proteinase-activated receptors. Pharmacol Rev 53: 245-282, 2001.

5. Coughlin SR: Thrombin signalling and protease-activated receptors. Nature 407: 258-264, 2000.

6. Coughlin SR: How the protease thrombin talks to cells. Proc Natl Acad Sci USA 96: 11023-11027, 1999.

7. Hollenberg MD and Compton SJ: International Union of Pharmacology. XXVIII. Proteinase-activated receptors. Pharmacol Rev 54: 203-217, 2002.

8. Ossovskaya VS and Bunnett NW: Protease-activated receptors: contribution to physiology and disease. Physiol Rev 84: 579-621, 2004

9. Vu TK, Hung DT, Wheaton VI and Coughlin SR: Molecular cloning of a functional thrombin receptor reveals a novel proteolytic mechanism of receptor activation. Cell 64: 1057-1068, 1991.

10. Ishihara H, Connolly AJ, Zeng D, Kahn ML, Zheng YW, Timmons C, Tram T and Coughlin SR: Protease-activated receptor 3 is a second thrombin receptor in humans. Nature 386: 502-506, 1997.

11. Xu WF, Andersen H, Whitmore TE, Presnell SR, Yee DP, Ching A, Gilbert T, Davie EW and Foster DC: Cloning and characterization of human protease-activated receptor 4. Proc Nat Acad Sci USA 95: 6642-6646, 1998.

12. Coughlin SR and Camerer E: PARticipation in inflammation. J Clin Invest 111: 25-27, 2003

13. Kondo K and Kaelin WG Jr: The von Hippel-Lindau tumor suppressor gene. Exp Cell Res 264: 117-125, 2001.

14. Ohh M, Yauch RL, Lonergan KM, Whaley JM, Stemmer-Rachamimov AO, Louis DN, Gavin BJ, Kley N, Kaelin WG Jr and Iliopoulos O: The von Hippel-Lindau tumor suppressor protein is required for proper assembly of an extracellular fibronectin matrix. Mol Cell 1: 959-968, 1998.

15. Zacharski LR, Memoli VA, Morain WD, Schlaeppi JM and Rousseau SM: Cellular localization of enzymatically active thrombin in intact human tissues by hirudin binding. Thromb Haemost 73: 793-797, 1995.

16. Rickles FR, Patierno S and Fernandez PM: Tissue factor, thrombin, and cancer. Chest 124: S58-S68, 2003.

17. Maragoudakis ME, Tsopanoglou NE and Andriopoulou P: Mechanism of thrombin-induced angiogenesis. Biochem Soc Trans 30: 173-177, 2002.

18. Tsopanoglou NE, Pipili-Synetos E and Maragoudakis ME: Thrombin promotes angiogenesis by a mechanism independent of fibrin formation. Am J Physiol 264: C1302-C1307, 1993.

19. Haralabopoulos GC, Grant DS, Kleinman HK and Maragoudakis ME: Thrombin promotes endothelial cell alignment in Matrigel in vitro and angiogenesis in vivo. Am J Physiol 273: C239-C245, 1997.

20. Fujiwara M, Jin E, Ghazizadeh M and Kawanami O: Activation of PAR4 induces a distinct actin fiber formation via p38 MAPK in human lung endothelial cells. J Histochem Cytochem 53: 1121-1129, 2005.

21. Vliagoftis $\mathrm{H}$ : Thrombin induces mast cell adhesion to fibronectin: evidence for involvement of protease-activated receptor-1. J Immunol 169: 4551-4558, 2002.

22. Kataoka H, Hamilton JR, McKemy DD, Camerer E, Zheng YW, Cheng A, Griffin C and Coughlin SR: Protease-activated receptors 1 and 4 mediate thrombin signaling in endothelial cells. Blood 102: 3224-3231, 2003.
23. Dimitropoulou C, Malkusch W, Fait E, Maragoudakis ME and Konerding MA: The vascular architecture of the chick chorioallantoic membrane: sequential quantitative evaluation using corrosion casting. Angiogenesis 2: 255-263, 1998.

24. Tsopanoglou NE and Maragoudakis ME: On the mechanism of thrombin-induced angiogenesis: inhibition of attachment of endothelial cells on basement membrane components. Angiogenesis 1: 192-200, 1998.

25. Maragoudakis ME, Kraniti N, Giannopoulou E, Alexopoulos K and Matsoukas J: Modulation of angiogenesis and progelatinase a by thrombin receptor mimetics and antagonists. Endothelium 8: 195-205, 2001.

26. Brooks PC, Strömblad S, Sanders LC, von Schalscha TL, Aimes RT, Stetler-Stevenson WG, Quigley JP and Cheresh DA: Localization of matrix metalloproteinase MMP-2 to the surface of invasive cells by interaction with integrin alpha $\mathrm{v}$ beta 3 . Cell 85: 683-693, 1996.

27. Tsopanoglou NE and Maragoudakis ME: On the mechanism of thrombin-induced angiogenesis. Potentiation of vascular endothelial growth factor activity on endothelial cells by up-regulation of its receptors. J Biol Chem 274: 23969-23976, 1999.

28. Liu Y and Mueller BM: Protease-activated receptor-2 regulates vascular endothelial growth factor expression in MDA-MB-231 cells via MAPK pathways. Biochem Biophys Res Commun 344: 1263-1270, 2006.

29. Marutsuka K, Hatakeyama K, Sato Y, Yamashita A, Sumiyoshi A and Asada Y: Protease-activated receptor 2 (PAR2) mediates vascular smooth muscle cell migration induced by tissue factor/ factor VIIa complex. Thromb Res 107: 271-276, 2002.

30. Oikonomopoulou K, Hansen KK, Saifeddine M, Vergnolle N, Tea I, Diamandis EP and Hollenberg MD: Proteinase-mediated cell signalling: targeting proteinase-activated receptors (PARs) by kallikreins and more. Biol Chem 387: 677-685, 2006.

31. Brooks PC, Clark RA and Cheresh DA: Requirement of vascular integrin alpha $v$ beta 3 for angiogenesis. Science 264: 569-571, 1994.

32. Nelken NA, Soifer SJ, O'Keefe J, Vu TK, Charo IF and Coughlin SR: Thrombin receptor expression in normal and atherosclerotic human arteries. J Clin Invest 90: 1614-1621, 1992.

33. Mirza H, Yatsula V and Bahou WF: The proteinase activated receptor-2 (PAR-2) mediates mitogenic responses in human vascular endothelial cells. J Clin Invest 97: 1705-1714, 1996.

34. Schmidt VA, Nierman WC, Maglott DR, Cupit LD, Moskowitz KA, Wainer JA and Bahou WF: The human proteinase-activated receptor-3 (PAR-3) gene. Identification within a Par gene cluster and characterization in vascular endothelial cells and platelets. J Biol Chem 273: 15061-15068, 1998.

35. Camerer E, Huang W and Coughlin SR: Tissue factor- and factor X-dependent activation of protease-activated receptor 2 by factor VIIa. Proc Natl Acad Sci USA 97: 5255-5260, 2000.

36. Riewald M and Ruf W: Mechanistic coupling of protease signaling and initiation of coagulation by tissue factor. Proc Natl Acad Sci USA 98: 7742-7747, 2001.

37. Camerer E, Kataoka H, Kahn M, Lease K and Coughlin SR: Genetic evidence that protease-activated receptors mediate factor Xa signaling in endothelial cells. J Biol Chem 277: 16081-16087, 2002.

38. Garcia JG, Davis HW and Patterson CE: Regulation of endothelial cell gap formation and barrier dysfunction: role of myosin light chain phosphorylation. J Cell Physiol 163: 510-522, 1995.

39. Vouret-Craviari V, Bourcier C, Boulter E and van Obberghen-Schilling E: Distinct signals via Rho GTPases and Src drive shape changes by thrombin and sphingosine1-phosphate in endothelial cells. J Cell Sci 115: 2475-2484, 2002

40. Minami T, Sugiyama A, Wu SQ, Abid R, Kodama T and Aird WC: Thrombin and phenotypic modulation of the endothelium. Arterioscler Thromb Vasc Biol 24: 41-53, 2004.

41. Carmeliet P: Angiogenesis in life, disease and medicine. Nature 438: 932-936, 2005.

42. Pinedo HM, Verheul HM, D'Amato RJ and Folkman J: Involvement of platelets in tumour angiogenesis? Lancet 352: 1775-1777, 1998.

43. Kakkar AK, Levine MN, Kadziola Z, Lemoine NR, Low V, Patel HK, Rustin G, Thomas M, Quigley M and Williamson RC: Low molecular weight heparin, therapy with dalteparin, and survival in advanced cancer: the fragmin advanced malignancy outcome study (FAMOUS). J Clin Oncol 22: 1944-1948, 2004. 
44. Klerk CP, Smorenburg SM, Otten HM, Lensing AW, Prins MH, Piovella F, Prandoni P, Bos MM, Richel DJ, van Tienhoven G and Büller HR: The effect of low molecular weight heparin on survival in patients with advanced malignancy. J Clin Oncol 23: 2130-2135, 2005.

45. Browder T, Folkman J and Pirie-Shepherd S: The hemostatic system as a regulator of angiogenesis. J Biol Chem 275: $1521-1524,2000$.

46. Folkman J, Browder T and Palmblad J: Angiogenesis research: guidelines for translation to clinical application. Thromb Haemost 86: 23-33, 2001.

47. Kisucka J, Butterfield CE, Duda DG, Eichenberger SC, Saffaripour S, Ware J, Ruggeri ZM, Jain RK, Folkman J and Wagner DD: Platelets and platelet adhesion support angiogenesis while preventing excessive hemorrhage. Proc Natl Acad Sci USA 103: 855-860, 2006.

48. Ma L, Perini R, McKnight W, Dicay M, Klein A, Hollenberg MD and Wallace JL: Proteinase-activated receptors 1 and 4 counterregulate endostatin and VEGF release from human platelets. Proc Natl Acad Sci USA 102: 216-220, 2005.

49. Pipili-Synetos E, Papadimitriou E and Maragoudakis ME: Evidence that platelets promote tube formation by endothelial cells on matrigel. Br J Pharmacol 125: 1252-1257, 1998.

50. Italiano JE Jr, Richardson JL, Patel-Hett S, Battinelli E, Zaslavsky A, Short S, Ryeom S, Folkman J and Klement GL: Angiogenesis is regulated by a novel mechanism: pro- and antiangiogenic proteins are organized into separate platelet alpha granules and differentially released. Blood 111: 1227-1233, 2008.

51. Möhle R, Green D, Moore MA, Nachman RL and Rafii S: Constitutive production and thrombin-induced release of vascular endothelial growth factor by human megakaryocytes and platelets. Proc Natl Acad Sci USA 94: 663-668, 1997.

52. Wartiovaara U, Salven P, Mikkola H, Lassila R, Kaukonen J, Joukov V, Orpana A, Ristimäki A, Heikinheimo M, Joensuu H, Alitalo $\mathrm{K}$ and Palotie A: Peripheral blood platelets express VEGF-C and VEGF which are released during platelet activation. Thromb Haemost 80: 171-175, 1998.

53. Kaplan DR, Chao FC, Stiles CD, Antoniades HN and Scher CD Platelet alpha granules contain a growth factor for fibroblasts. Blood 53: 1043-1052, 1979.

54. Ben-Ezra J, Sheibani K, Hwang DL and Lev-Ran A: Megakaryocyte synthesis is the source of epidermal growth factor in human platelets. Am J Pathol 137: 755-759, 1990.

55. Nakamura T, Tomita Y, Hirai R, Yamaoka K, Kaji $\mathrm{K}$ and Ichihara A: Inhibitory effect of transforming growth factor-beta on DNA synthesis of adult rat hepatocytes in primary culture. Biochem Biophys Res Commun 133: 1042-1050, 1985.

56. Hla T: Physiological and pathological actions of sphingosine 1-phosphate. Semin Cell Dev Biol 15: 513-520, 2004.

57. Galt SW, Lindemann S, Allen L, Medd DJ, Falk JM, McIntyre TM, Prescott SM, Kraiss LW, Zimmerman GA and Weyrich AS: Outside-in signals delivered by matrix metalloproteinase-1 regulate platelet function. Circ Res 90: 1093-1099, 2002.

58. Daly ME, Makris A, Reed M and Lewis CE: Hemostatic regulators of tumor angiogenesis: a source of anti-angiogenic agents for cancer treatment? J Natl Cancer Inst 95: 1660-1673, 2003.

59. Iruela-Arispe ML, Bornstein $\mathrm{P}$ and Sage $\mathrm{H}$ : Thrombospondin exerts an anti-angiogenic effect on cord formation by endothelial cells in vitro. Proc Natl Acad Sci USA 88: 5026-5030, 1991.

60. Maione TE, Gray GS, Petro J, Hunt AJ, Donner AL, Bauer SI, Carson HF and Sharpe RJ: Inhibition of angiogenesis by recombinant human platelet factor- 4 and related peptides. Science 247 : $77-79,1990$

61. Covic L, Gresser AL and Kuliopulos A: Biphasic kinetics of activation and signaling for PAR 1 and PAR4 thrombin receptors in platelets. Biochemistry 39: 5458-5467, 2000.

62. Jamieson GA: Pathophysiology of platelet thrombin receptors Thromb Haemost 78: 242-246, 1997.

63. Cottrell GS, Coelho AM and Bunnett NW: Protease-activated receptors: the role of cell-surface proteolysis in signalling. Essays Biochem 38: 169-183, 2002.

64. Kahn ML, Zheng YW, Huang W, Bigornia V, Zeng D, Moff S, Farese RV Jr, Tam C and Coughlin SR: A dual thrombin receptor system for platelet activation. Nature 394: 690-694, 1998.

65. Coughlin SR: Protease-activated receptors in hemostasis, thrombosis and vascular biology. J Thromb Haemost 3: 1800-1814, 2005 .
66. Brass LF: Thrombin and platelet activation. Chest 124: S18-S25, 2003.

67. Vandendries ER, Hamilton JR, Coughlin SR, Furie B and Furie BC: Par4 is required for platelet thrombus propagation but not fibrin generation in a mouse model of thrombosis. Proc Natl Acad Sci USA 104: 288-292, 2007.

68. Holinstat M, Voss B, Bilodeau ML and Hamm HE: Proteaseactivated receptors differentially regulate human platelet activation through a phosphatidic acid-dependent pathway. Mol Pharmacol 71: 686-694, 2007.

69. Holinstat M, Voss B, Bilodeau ML, McLaughlin JN, Cleator J and Hamm HE: PAR4, but not PAR1, signals human platelet aggregation via $\mathrm{Ca}^{+}$mobilization and synergistic $\mathrm{P} 2 \mathrm{Y} 12$ receptor activation. J Biol Chem 281: 26665-26674, 2006.

70. Kahn ML, Nakanishi-Matsui M, Shapiro MJ, Ishihara H and Coughlin SR: Protease-activated receptors 1 and 4 mediate activation of human platelets by thrombin. J Clin Invest 103: 879-887, 1999.

71. Andersen H, Greenberg DL, Fujikawa K, Xu W, Chung DW and Davie EW: Protease-activated receptor 1 is the primary mediator of thrombin-stimulated platelet procoagulant activity. Proc Natl Acad Sci USA 96: 11189-11193, 1999.

72. Wu CC, Wu SY, Liao CY, Teng CM, Wu YC and Kuo SC: The roles and mechanisms of PAR4 and P2Y12/phosphatidylinositol 3-kinase pathway in maintaining thrombin-induced platelet aggregation. Br J Pharmacol 161: 643-658, 2010.

73. Shapiro MJ, Weiss EJ, Faruqi TR and Coughlin SR: Proteaseactivated receptors 1 and 4 are shut off with distinct kinetics after activation by thrombin. J Biol Chem 275: 25216-25221, 2000.

74. Nierodzik ML, Plotkin A, Kajumo F and Karpatkin S: Thrombin stimulates tumor-platelet adhesion in vitro and metastasis in vivo. J Clin Invest 87: 229-236, 1991.

75. Nierodzik ML, Kajumo F and Karpatkin S: Effect of thrombin treatment of tumor cells on adhesion of tumor cells to platelets in vitro and tumor metastasis in vivo. Cancer Res 52: 3267-3272, 1992.

76. Darmoul D, Gratio V, Devaud H, Lehy T and Laburthe M: Aberrant expression and activation of the thrombin receptor protease-activated receptor-1 induces cell proliferation and motility in human colon cancer cells. Am J Pathol 162: 1503-1513, 2003.

77. Darmoul D, Gratio V, Devaud H, Peiretti F and Laburthe M: Activation of proteinase-activated receptor 1 promotes human colon cancer cell proliferation through epidermal growth factor receptor transactivation. Mol Cancer Res 2: 514-522, 2004.

78. Chiang HS, Yang RS and Huang TF: Thrombin enhances the adhesion and migration of human colon adenocarcinoma cells via increased beta 3-integrin expression on the tumour cell surface and their inhibition by the snake venom peptide, rhodostomin. Br J Cancer 73: 902-908, 1996.

79. Chen HT, Tsou HK, Tsai CH, Kuo CC, Chiang YK, Chang $\mathrm{CH}$, Fong $\mathrm{YC}$ and Tang $\mathrm{CH}$ : Thrombin enhanced migration and MMPs expression of human chondrosarcoma cells involves PAR receptor signaling pathway. J Cell Physiol 223: 737-745, 2010.

80. Kaufmann R, Rahn S, Pollrich K, Hertel J, Dittmar Y, Hommann M, Henklein P, Biskup C, Westermann M, Hollenberg MD and Settmacher U: Thrombin-mediated hepatocellular carcinoma cell migration: cooperative action via proteinase-activated receptors 1 and 4. J Cell Physiol 211: 699-707, 2007.

81. Miyata S, Koshikawa N, Yasumitsu H and Miyazaki K: Trypsin stimulates integrin alpha(5)beta(1)-dependent adhesion to fibronectin and proliferation of human gastric carcinoma cells through activation of proteinase-activated receptor-2. J Biol Chem 275: 4592-4598, 2000

82. Even-Ram S, Uziely B, Cohen P, Grisaru-Granovsky S, Maoz M, Ginzburg Y, Reich R, Vlodavsky I and Bar-Shavit R: Thrombin receptor overexpression in malignant and physiological invasion processes. Nat Med 4: 909-914, 1998.

83. Wojtukiewicz MZ, Tang DG, Nelson KK, Walz DA, Diglio CA and Honn KV: Thrombin enhances tumor cell adhesive and metastatic properties via increased alpha IIb beta 3 expression on the cell surface. Thromb Res 68: 233-245, 1992.

84. Wojtukiewicz MZ, Tang DG, Ciarelli JJ, Nelson KK, Walz DA, Diglio CA, Mammen EF and Honn KV: Thrombin increases the metastatic potential of tumor cells. Int J Cancer 54: 793-806, 1993. 
85. Hughes PE and Pfaff M: Integrin affinity modulation. Trends Cell Biol 8: 359-364, 1998.

86. Hattori R, Hamilton KK, Fugate RD, McEver RP and Sims PJ: Stimulated secretion of endothelial von Willebrand factor is accompanied by rapid redistribution to the cell surface of the intracellular granule membrane protein GMP-140. J Biol Chem 264: 7768-7771, 1989.

87. Stenberg PE, McEver RP, Shuman MA, Jacques YV and Bainton DF: A platelet alpha-granule membrane protein (GMP-140) is expressed on the plasma membrane after activation. J Cell Biol 101: 880-886, 1985.

88. Henn V, Slupsky JR, Gräfe M, Anagnostopoulos I, Förster R, Müller-Berghaus G and Kroczek RA: CD40 ligand on activated platelets triggers an inflammatory reaction of endothelial cells. Nature 391: 591-594, 1998

89. Daniel TO, Gibbs VC, Milfay DF, Garovoy MR and Williams LT: Thrombin stimulates c-sis gene expression in microvascular endothelial cells. J Biol Chem 261: 9579-9582, 1986.

90. Papadimitriou E, Manolopoulos VG, Hayman GT, Maragoudakis ME, Unsworth BR, Fenton JW II and Lelkes PI: Thrombin modulates vectorial secretion of extracellular matrix proteins in cultured endothelial cells. Am J Physiol 272: C1112-C1122, 1997.

91. Wojtukiewicz MZ, Tang DG, Ben-Josef E, Renaud C, Walz DA and Honn KV: Solid tumor cells express functional 'tethered ligand' thrombin receptor. Cancer Res 55: 698-704, 1995

92. Camerer E: Protease signaling in tumor progression. Thromb Res 120: S75-S81, 2007.

93. Bohm SK, Kong W, Bromme D, Smeekens SP, Anderson DC, Connolly A, Kahn M, Nelken NA, Coughlin SR, Payan DG and Bunnett NW: Molecular cloning, expression and potential functions of the human proteinase-activated receptor-2. Biochem J 314: 1009-1016, 1996.

94. D'Andrea MR, Derian CK, Santulli RJ and Andrade-Gordon P: Differential expression of protease-activated receptors-1 and -2 in stromal fibroblasts of normal, benign, and malignant human tissues. Am J Pathol 158: 2031-2041, 2001.

95. Darmoul D, Marie JC, Devaud H, Gratio V and Laburthe M: Initiation of human colon cancer cell proliferation by trypsin acting at protease-activated receptor-2. Br J Cancer 85: 772-779, 2001 .

96. Nierodzik ML, Bain RM, Liu LX, Shivji M, Takeshita K and Karpatkin S: Presence of the seven transmembrane thrombin receptor on human tumour cells: effect of activation on tumour adhesion to platelets and tumor tyrosine phosphorylation. Br J Haematol 92: 452-457, 1996.

97. Henrikson KP, Salazar SL, Fenton JW II and Pentecost BT: Role of thrombin receptor in breast cancer invasiveness. Br J Cancer 79: 401-406, 1999.

98. Nierodzik ML, Chen K, Takeshita K, Li JJ, Huang YQ, Feng XS, D'Andrea MR, Andrade-Gordon $P$ and Karpatkin $S$ Protease-activated receptor 1 (PAR-1) is required and ratelimiting for thrombin-enhanced experimental pulmonary metastasis. Blood 92: 3694-3700, 1998.

99. Gratio V, Walker F, Lehy T, Laburthe M and Darmoul D: Aberrant expression of proteinase-activated receptor 4 promotes colon cancer cell proliferation through a persistent signaling that involves Src and ErbB-2 kinase. Int J Cancer 124: 1517-1525, 2009.

100. Bergmann S, Junker K, Henklein P, Hollenberg MD, Settmacher U and Kaufmann R: PAR-type thrombin receptors in renal carcinoma cells: PAR1-mediated EGFR activation promotes cell migration. Oncol Rep 15: 889-893, 2006.

101. Jin E, Fujiwara M, Pan X, Ghazizadeh M, Arai S, Ohaki Y, Kajiwara K, Takemura T and Kawanami O: Protease-activated receptor (PAR)-1 and PAR-2 participate in the cell growth of alveolar capillary endothelium in primary lung adenocarcinomas. Cancer 97: 703-713, 2003.

102. Fischer EG, Ruf W and Mueller BM: Tissue factor-initiated thrombin generation activates the signaling thrombin receptor on malignant melanoma cells. Cancer Res 55: 1629-1632, 1995.

103. Kaufmann R, Henklein P, Henklein P and Settmacher U: Green tea polyphenol epigallocatechin-3-gallate inhibits thrombininduced hepatocellular carcinoma cell invasion and $\mathrm{p} 42 /$ p44-MAPKinase activation. Oncol Rep 21: 1261-1267, 2009

104. Faruqi TR, Weiss EJ, Shapiro MJ, Huang W and Coughlin SR: Structure-function analysis of protease-activated receptor 4 tethered ligand peptides. Determinants of specificity and utility in assays of receptor function. J Biol Chem 275: 19728-19734, 2000.
105. Rickles FR, Levine M and Edwards RL: Hemostatic alterations in cancer patients. Cancer Metastasis Rev 11: 237-248, 1992

106. Walz DA and Fenton JW: The role of thrombin in tumor cell metastasis. Invasion Metastasis 14: 303-308, 1994.

107. Ruf W and Mueller BM: Tissue factor in cancer angiogenesis and metastasis. Curr Opin Hematol 3: 379-84, 1996.

108. Palumbo JS and Degen JL: Hemostatic factors in tumor biology. J Pediatr Hematol Oncol 22: 281-287, 2000.

109. Hejna M, Raderer M and Zielinski CC: Inhibition of metastases by anticoagulants. J Natl Cancer Inst 91: 22-36, 1999.

110. Tellez C and Bar-Eli M: Role and regulation of the thrombin receptor (PAR-1) in human melanoma. Oncogene 22: 3130-3137, 2003.

111. Shi X, Gangadharan B, Brass LF, Ruf W and Mueller BM: Protease-activated receptors (PAR1 and PAR2) contribute to tumor cell motility and metastasis. Mol Cancer Res 2: 395-402, 2004.

112. Even-Ram SC, Maoz M, Pokroy E, Reich R, Katz BZ, Gutwein P, Altevogt P and Bar-Shavit R: Tumor cell invasion is promoted by activation of protease activated receptor- 1 in cooperation with the alpha vbeta 5 integrin. J Biol Chem 276: 10952-10962, 2001.

113. Turcotte S, Desrosiers RR, Brand G and Béliveau R: von HippelLindau tumor suppressor protein stimulation by thrombin involves RhoA activation. Int J Cancer 112: 777-786, 2004.

114. Chay CH, Cooper CR, Gendernalik JD, Dhanasekaran SM, Chinnaiyan AM, Rubin MA, Schmaier AH and Pienta KJ: A functional thrombin receptor (PAR1) is expressed on bonederived prostate cancer cell lines. Urology 60: 760-765, 2002.

115. Bromberg ME, Bailly MA and Konigsberg WH: Role of protease-activated receptor 1 in tumor metastasis promoted by tissue factor. Thromb Haemost 86: 1210-1214, 2001.

116. Fischer EG, Riewald M, Huang HY, Miyagi Y, Kubota Y, Mueller BM and Ruf W: Tumor cell adhesion and migration supported by interaction of a receptor-protease complex with its inhibitor. J Clin Invest 104: 1213-1221, 1999.

117. Karpatkin S: Does hypercoagulability awaken dormant tumor cells in the host? J Thromb Haemost 2: 2103-2106, 2004

118. Yin YJ, Salah Z, Grisaru-Granovsky S, Cohen I, Even-Ram SC, Maoz M, Uziely B, Peretz T and Bar-Shavit R: Human proteaseactivated receptor 1 expression in malignant epithelia: a role in invasiveness. Arterioscler Thromb Vasc Biol 23: 940-944, 2003.

119. O'Brien PJ, Prevost N, Molino M, Hollinger MK, Woolkalis MJ, Woulfe DS and Brass LF: Thrombin responses in human endothelial cells. Contributions from receptors other than PAR1 include the transactivation of PAR2 by thrombin-cleaved PAR1. J Biol Chem 275: 13502-13509, 2000.

120.Zacharski LR and Ornstein DL: Heparin and cancer. Thromb Haemost 80: 10-23, 1998.

121. Smorenburg SM, Hettiarachchi RJ, Vink R and Büller HR: The effects of unfractionated heparin on survival in patients with malignancy - a systematic review. Thromb Haemost 82: 1600-1604, 1999.

122.Zacharski LR, Ornstein DL and Mamourian AC: Low-molecular-weight heparin and cancer. Semin Thromb Hemost 26: 69-77, 2000 .

123. Teng LS, Jin KT, He KF, Wang HH, Cao J and Yu DC: Advances in combination of anti-angiogenic agents targeting VEGF-binding and conventional chemotherapy and radiation for cancer treatment. J Chin Med Assoc 73: 281-288, 2010.

124. Teng LS, Jin KT, He KF, Zhang J, Wang HH and Cao J: Clinical applications of VEGF-trap (aflibercept) in cancer treatment. J Chin Med Assoc 73: 449-456, 2010.

125. Jin K, Shen Y, He K, Xu Z, Li G and Teng L: Aflibercept (VEGF Trap): one more double-edged sword of anti-VEGF therapy for cancer? Clin Transl Oncol 12: 526-532, 2010.

126. Edwards RL, Klaus M, Matthews E, McCullen C, Bona RD and Rickles FR: Heparin abolishes the chemotherapy-induced increase in plasma fibrinopeptide A levels. Am J Med 89: 25-28, 1990.

127. Zangari M, Anaissie E, Barlogie B, Badros A, Desikan R, Gopal AV, Morris C, Toor A, Siegel E, Fink L and Tricot G: Increased risk of deep-vein thrombosis in patients with multiple myeloma receiving thalidomide and chemotherapy. Blood 98 1614-1615, 2001

128. Varki NM and Varki A: Heparin inhibition of selectin-mediated interactions during the hematogenous phase of carcinoma metastasis: rationale for clinical studies in humans. Semin Thromb Hemost 28: 53-66, 2002. 
129. Collen A, Smorenburg SM, Peters E, Lupu F, Koolwijk P, van Noorden $C$ and van Hinsbergh VW: Unfractionated and low molecular weight heparin affect fibrin structure and angiogenesis in vitro. Cancer Res 60: 6196-6200, 2000.

130. Mousa SA: Anticoagulants in thrombosis and cancer: the missing link. Semin Thromb Hemost 28: 45-52, 2002.

131. Norrby K and Ostergaard P: Basic-fibroblast-growth-factormediated de novo angiogenesis is more effectively suppressed by low-molecular-weight than by high-molecular-weight heparin. Int J Microcirc Clin Exp 16: 8-15, 1996.

132. Hirsh J: Current anticoagulant therapy - unmet clinical needs. Thromb Res 109: S1-S8, 2003.

133. Weitz JI: A novel approach to thrombin inhibition. Thromb Res 109: S17-S22, 2003.

134. Pakala R, Liang CT and Benedict CR: Inhibition of arterial thrombosis by a peptide ligand of the thrombin receptor. Thromb Res 100: 89-96, 2000.

135. Covic L, Misra M, Badar J, Singh C and Kuliopulos A: Pepducin-based intervention of thrombin-receptor signaling and systemic platelet activation. Nat Med 8: 1161-1165, 2002.

136. Kasuda S, Sakurai Y, Shima M, Morimura Y, Kudo R, Takeda T, Ishitani A, Yoshioka A and Hatake K: Inhibition of PAR4 signaling mediates ethanol-induced attenuation of platelet function in vitro. Alcohol Clin Exp Res 30: 1608-1614, 2006.

137. Derian CK, Maryanoff BE, Zhang HC and Andrade-Gordon P: Therapeutic potential of protease-activated receptor-1 antagonists. Expert Opin Investig Drugs 12: 209-221, 2003.

138. Wu CC and Teng CM: Comparison of the effects of PAR1 antagonists, PAR4 antagonists, and their combinations on thrombininduced human platelet activation. Eur J Pharmacol 546: 142-147, 2006.

139. Andrade-Gordon P, Maryanoff BE, Derian CK, et al: Design, synthesis, and biological characterization of a peptide-mimetic antagonist for a tethered-ligand receptor. Proc Natl Acad Sci USA 96: 12257-12262, 1999 .

140. Maryanoff BE, Zhang HC, Andrade-Gordon P and Derian CK: Discovery of potent peptide-mimetic antagonists for the human thrombin receptor, protease-activated receptor-1 (PAR-1). Curr Med Chem Cardiovasc Hematol Agents 1: 13-36, 2003.

141. Zhang HC, Derian CK, Andrade-Gordon P, et al: Discovery and optimization of a novel series of thrombin receptor (par-1) antagonists: potent, selective peptide mimetics based on indole and indazole templates. J Med Chem 44: 1021-1024, 2001.

142. Derian CK, Damiano BP, Addo MF, Darrow AL, D'Andrea MR, Nedelman M, Zhang HC, Maryanoff BE and AndradeGordon P: Blockade of the thrombin receptor protease-activated receptor-1 with a small-molecule antagonist prevents thrombus formation and vascular occlusion in nonhuman primates. J Pharmacol Exp Ther 304: 855-861, 2003.

143. Chackalamannil S, Xia Y, Greenlee WJ, Clasby M, Doller D, Tsai H, Asberom T, Czarniecki M, Ahn HS, Boykow G, Foster C, Agans-Fantuzzi J, Bryant M, Lau J and Chintala M: Discovery of potent orally active thrombin receptor (protease activated receptor 1) antagonists as novel antithrombotic agents. J Med Chem 48: 5884-5887, 2005.
144. Reséndiz JC, Kroll MH and Lassila R: Protease-activated receptor-induced Akt activation - regulation and possible function. J Thromb Haemost 5: 2484-2493, 2007.

145. Mao Y, Jin J, Daniel JL and Kunapuli SP: Regulation of plasmin-induced protease-activated receptor 4 activation in platelets. Platelets 20: 191-198, 2009.

146. Seiler SM and Bernatowicz MS: Peptide-derived proteaseactivated receptor-1 (PAR-1) antagonists. Curr Med Chem Cardiovasc Hematol Agents 1: 1-11, 2003.

147. Strande JL, Hsu A, Su J, Fu X, Gross GJ and Baker JE: Inhibiting protease-activated receptor 4 limits myocardial ischemia/reperfusion injury in rat hearts by unmasking adenosine signaling. J Pharmacol Exp Ther 324: 1045-1054, 2008.

148. Hollenberg MD and Saifeddine M: Proteinase-activated receptor 4(PAR4): activation and inhibition of rat platelet aggregation by PAR4-derived peptides. Can J Physiol Pharmacol 79: 439-442, 2001.

149. Ma L, Hollenberg MD and Wallace JL: Thrombin-induced platelet endostatin release is blocked by a proteinase activated receptor-4 (PAR4) antagonist. Br J Pharmacol 134: 701-704, 2001 .

150. Kuliopulos A and Covic L: Blocking receptors on the inside: pepducin-based intervention of PAR signaling and thrombosis. Life Sci 74: 255-262, 2003

151. Wu CC, Hwang TL, Liao CH, Kuo SC, Lee FY, Lee CY and Teng CM: Selective inhibition of protease-activated receptor 4-dependent platelet activation by YD-3. Thromb Haemost 87: 1026-1033, 2002.

152. Sangawa T, Nogi T and Takagi J: A murine monoclonal antibody that binds N-terminal extracellular segment of human proteaseactivated receptor-4. Hybridoma 27: 331-335, 2008.

153. O'Brien PJ, Molino M, Kahn M and Brass LF: Protease activated receptors: theme and variations. Oncogene 20: 1570-1581, 2001.

154. Nantermet PG, Barrow JC, Lundell GF, et al: Discovery of a nonpeptidic small molecule antagonist of the human platelet thrombin receptor (PAR-1). Bioorg Med Chem Lett 12: 319-323, 2002.

155. Kato Y, Kita Y, Hirasawa-Taniyama Y, Nishio M, Mihara K, Ito K, Yamanaka T, Seki J, Miyata S and Mutoh S: Inhibition of arterial thrombosis by a protease-activated receptor 1 antagonist, FR171113, in the guinea pig. Eur J Pharmacol 473: 163-169, 2003.

156. Hollenberg MD, Saifeddine M, Sandhu S, Houle S and Vergnolle N: Proteinase-activated receptor-4: evaluation of tethered ligand-derived peptides as probes for receptor function and as inflammatory agonists in vivo. Br J Pharmacol 143: 443-454, 2004.

157. Covic L, Gresser AL, Talavera J, Swift S and Kuliopulos A: Activation and inhibition of $\mathrm{G}$ protein-coupled receptors by cell-penetrating membrane-tethered peptides. Proc Natl Acad Sci USA 99: 643-648, 2002. 